\title{
Water productivity and agronomic performance of strawberries with different leaching fractions application
}

\author{
Produtividade da água e desempenho agronômico do morangueiro com aplicação de diferentes \\ frações de lixiviação
}

\author{
M. L. Gontijo ${ }^{1}$, A. V. Diotto ${ }^{2 *}$, F. S. de Souza $^{3}$, F. L. Gontijo ${ }^{4}$ \\ ${ }^{1}$ Departamento de Recursos Hídricos, Universidade Federal de Lavras, 37200-000, Lavras - MG. \\ ${ }^{2}$ Departamento de Recursos Hídricos, Universidade Federal de Lavras, 37200-000, Lavras - MG. \\ ${ }^{3}$ Departamento de Fitotecnia, Universidade Federal de Viçosa, Viçosa-MG. \\ ${ }^{4}$ Departamento de Veterinária, Universidade Federal de Lavras, Lavras - MG. \\ *adriano.diotto@ufla.br
}

(Recebido em 07 de outubro de 2019; aceito em 16 de maio de 2020)

\begin{abstract}
Strawberry is an economically important crop. However, because this crop is very susceptible to pests and diseases, the use of new management techniques, such as semi-hydroponic cultivation, is necessary. One of the greatest difficulties for producers in the transition from soil to semi-hydroponic cultivation is fertigation management. As most crops in Brazil are grown in open fields, monitoring the electrical conductivity of the drained solution is key. Thus, the aim of this study was to use different leaching fractions to evaluate the control of saline levels and the productivity of the San Andreas strawberry. The experimental design was completely randomized. The treatments consisted of different leaching fractions, equivalent to $10,20,30$, and $50 \%$ excess irrigation. Most of the evaluated traits were significantly affected at the 5\% level of significance according to Tukey's test. The 30\% leaching fraction showed the best results in practically all evaluations, with better values obtained even for water productivity and with $19.92 \mathrm{~g}$ of fruit per liter of solution used.

Keywords: strawberry, semihydroponic, fertigation
\end{abstract}

O morangueiro é uma cultura de grande importância econômica. Mas por ser muito susceptível ao ataque de pragas e doenças tornou-se necessária a utilização de novas técnicas de manejo, como o cultivo semihidropônico. Uma das maiores dificuldades dos produtores na transição do cultivo com solo para o semihidropônico é o manejo da fertirrigação. Como a maioria dos cultivos no Brasil é aberta, o monitoramento da condutividade elétrica da solução drenada é considerado um ponto chave. Assim, o objetivo do trabalho foi avaliar o controle dos níveis salinos e a produtividade do morangueiro San Andreas, com a utilização de diferentes frações de lixiviação. O delineamento experimental utilizado foi inteiramente casualizado. Tendo como tratamentos diferentes frações de lixiviação, equivalentes a 10, 20, 30 e $50 \%$ de excedente de irrigação. As características físicas dos frutos avaliadas, produção por planta e produtividade da água não foram afetadas significativamente a 5\% de significância pelo teste Tukey. Porém a condutividade elétrica da solução drenada foi menor no tratamento que recebeu $50 \%$ de fração de lixiviação.

Palavras-chave: morango, semi-hidropônico, fertirrigação

\section{INTRODUCTION}

Of great economic importance, the strawberry (Fragaria $x$ ananassa Duch.), which is consumed fresh or used in the food industry, is the most popular, most cultivated, and most consumed fruit among small fruits [1].

This is a crop grown on small farms in Brazil, where crop rotation is a factor limited by the size of the properties. Planting strawberries for several consecutive years increases the pressure of pests and diseases and has led to the development of new farming techniques that improve phytosanitary control and the use of water and energy resources. Soilless cultivation has emerged as an interesting alternative to try to minimize these problems and to enable production without contaminating the fruits $[2,3]$. Soilless cultivation can be done without the use of a support medium, such as hydroponics, where the roots are exposed, and solutions are intermittently added 
to a water solvent. An alternative is to use a system known as semihydroponics, where a nutrient solution is used intermittently, but the plants are placed in a substrate [4].

Growing crops in substrates has shown better results than traditional production systems in many studies [3]. However, one of the greatest difficulties reported by producers who transition from conventional to semihydroponic farming is fertigation management. As most crops in Brazil are grown in open fields and do not take advantage of the drainage system [5], monitoring the electrical conductivity of the drained solution is key, especially for crops that are very sensitive to salinity, such as strawberries [6], where the electrical conductivity of the soil solution should be maintained below $1.90 \mathrm{dS} \mathrm{m}{ }^{-1}$ [7]. For each unit increase in electrical conductivity, a $33 \%$ reduction occurs in production [8]. Salt stress can negatively affect both growth and nutrient absorption [6].

Several authors have suggested, as an alternative for the control of the accumulation of salts near the roots of the plants, the application of irrigation at approximately $30 \%$ excess for drainage to occur. The leaching fraction (LF) or leaching requirement is the amount of water that will be applied through irrigation and percolated out of the root system to decrease the salt accumulation [9].

Water productivity, which aims to evaluate production per unit of water used in both rainfed and irrigated conditions, is one of the concepts that has been playing a crucial role in the modern agricultural sector. According to van halsema and Vincent (2012) [10], this concept has value as an indicator for use at times and locations of relative water scarcity, for example.

In this context, the aim of this study was to evaluate the effect of different leaching fractions on water productivity and agronomic performance of the San Andreas strawberry.

\section{MATERIALS AND METHODS}

The present study was developed in the experimental area of the Department of Water Resources and Sanitation of the Federal University of Lavras, located at $21^{\circ} 14$ 'S, $45^{\circ} 00^{\prime} \mathrm{W}$ and $918 \mathrm{~m}$ average altitude. The climate classification of the region, according to Köppen, is Cwa (humid subtropical climate), which is characterized by a rainy temperate climate [11].

The seedlings were purchased from a reseller that imports them from an accredited nursery in Chile. The cultivar used was San Andreas, and it was transplanted on June 9, 2018 into slabs (bags), with four plants per slab and with each slab having a 15-L capacity and being filled with Carolina Soil ${ }^{\circledR}$ commercial substrate. The slabs were arranged randomly on four countertops within the protected environment and irrigated by dripping. One dripper with a flow of $4 \mathrm{~L} \mathrm{~h}^{-1}$ was used for each slab and divided into four drip stakes. Treatments were started 30 days after transplantation and were applied until November 13, 2018, for a total of 162 days.

Four different leaching fractions, which were determined daily by weighing the slabs, were evaluated: $10 \%$ (T1), $20 \%$ (T2), 30\% (T3), and 50\% (T4) more water than the volume consumed (evapotranspirated) by the crop. A completely randomized design was used, with five replicates and with each replicate containing a slab with four plants, for a total of twenty slabs and eighty plants.

The irrigation time was obtained by equation 1 .

$$
\mathrm{T}=\frac{60 \times V_{\mathrm{p}}}{\mathrm{Qg}_{\mathrm{g}}}
$$

in which

$\mathrm{T}=$ the irrigation time $(\mathrm{min})$,

$\mathrm{V}_{\mathrm{p}}=$ the volume to be irrigated $(\mathrm{L})$, and

$\mathrm{Q}_{\mathrm{g}}=$ the nominal flow rate of the dripper (in this case $4 \mathrm{~L} \mathrm{~h}^{-1}$ ).

During the experiments, maximum and minimum air temperature and relative humidity data were collected through a meteorological station installed inside the protected environment. Subsequently, the data obtained were compared with the data provided for the experimental period by the Instituto Nacional de Meteorologia (Brazilian Institute of Meteorology; INMET), which is close to the experimental area.

The nutrient solution was formulated according to the recommendation of Furlani and Fernandes-Junior (2004) [12] and maintained with electrical conductivity between 1.4 and $1.5 \mathrm{dS}$ 
$\mathrm{m}^{-1}$ [13] and $\mathrm{pH}$ between 5.5 and 6.5 [5]. The solution drained from slabs was collected weekly, and the values of electrical conductivity and $\mathrm{pH}$ were monitored to determine the behavior of the variables over time.

Harvests were performed one to three times a week according to fruit production and maturation. The evaluated variables were fruit diameter and length (measured with a digital caliper), mean fruit mass (determined with a digital scale), yield per plant, and the number of commercial fruits (those weighing more than $6 \mathrm{~g}$ ), without damage, diseases, or deformations [14]. The yield per plant (grams per plant) was obtained by the mass of fruits produced per treatment divided by the number of plants per treatment. The mean fruit mass was calculated by dividing the fresh weight per plant by the number of fruits per plant.

For the determination of water productivity as a function of fresh weight production per plant, equation 2 was used.

in which

$$
W P p=\frac{F M P}{T W}
$$

$\mathrm{WP}_{\mathrm{p}}=$ the water productivity relative to the production of fresh fruit mass $\left(\mathrm{g} \mathrm{L}^{-1}\right)$,

$\mathrm{FMP}=$ the fresh fruit mass production $\left(\mathrm{g} \mathrm{plant}^{-1}\right)$, and

$\mathrm{TW}=$ the total water applied $\left(\mathrm{L} \mathrm{plant}^{-1}\right)$.

Statistical analysis was performed using analysis of variance ( $F$ test) and regression analysis. Treatments were compared by Tukey's test at the 5\% level of significance.

\section{RESULTS AND DISCUSSION}

The mean minimum and maximum air temperatures obtained during the experiment within the protected environment were 15.1 and $29.4{ }^{\circ} \mathrm{C}$, respectively. The minimum and maximum temperatures of the external environment were 14.8 and $26.7^{\circ} \mathrm{C}$, respectively. As expected, due to the plastic cover, the temperature values within the protected environment were higher. According to Tazzo et al. (2015) [1], the mean air temperature within the protected environment was above the base temperature for strawberry development, which was $7{ }^{\circ} \mathrm{C}$ throughout the experiment. The average relative humidity obtained within the protected environment was a minimum of $33.4 \%$ and a maximum of $84.5 \%$, whereas those values obtained in the external environment were $50.4 \%$ and $82.9 \%$, minimum and maximum, respectively. According to Bortolozzo et al. (2007) [13], for pollination, the minimum temperature should be $12{ }^{\circ} \mathrm{C}$, and the relative humidity should be lower than $94 \%$, thus confirming that the temperature and relative humidity obtained in the protected environment were close to those considered ideal for pollination.

In Table 1, we show that the application of the different leaching fractions significantly influenced most of the parameters evaluated at the 5\% level of significance according to Tukey's test. According to Sousa et al. (2011) [15], the leaching volume reduces the accumulation of salts in the roots, avoiding the increase in salinity, which is beneficial to the crop; however, excess leaching can reduce the availability of nutrients to the plants and affect production. 
Table 1: Fruit diameter (FD), fruit length $(F L)$, mean weight per fruit $(F W)$, yield per plant $(Y P P)$, number of commercial fruits per plant $(N F)$, water productivity (WP), electrical conductivity (EC) and $p H$

\begin{tabular}{ccccccccc}
\hline \multirow{2}{*}{ Treatment } & FD & FL & FW & YPP & NF & WP & EC & pH \\
\cline { 2 - 8 } & $(\mathrm{mm})$ & $(\mathrm{mm})$ & $(\mathrm{g})$ & $\left(\mathrm{g} \mathrm{plant}^{-1}\right)$ & & $\left(\mathrm{g} \mathrm{L}^{-1}\right)$ & $\left(\mathrm{dS} \mathrm{m}^{-1}\right)$ & \\
\hline T1 & $28.88^{\mathrm{b}}$ & $36.75^{\mathrm{c}}$ & $13.52^{\mathrm{b}}$ & $250.10^{\mathrm{b}}$ & $20.36^{\mathrm{ab}}$ & $15.54^{\mathrm{b}}$ & $1.80^{\mathrm{ab}}$ & $6.15^{\mathrm{b}}$ \\
$\mathrm{T} 2$ & $31.11^{\mathrm{ab}}$ & $38.23^{\mathrm{bc}}$ & $16.85^{\mathrm{ab}}$ & $258.72^{\mathrm{b}}$ & $17.00^{\mathrm{b}}$ & $14.74^{\mathrm{b}}$ & $1.99^{\mathrm{a}}$ & $6.25^{\mathrm{ab}}$ \\
T3 & $31.85^{\mathrm{a}}$ & $40.70^{\mathrm{a}}$ & $18.27^{\mathrm{a}}$ & $378.9^{\mathrm{a}}$ & $24.11^{\mathrm{a}}$ & $19.92^{\mathrm{a}}$ & $1.93^{\mathrm{a}}$ & $6.20^{\mathrm{ab}}$ \\
T4 & $31.06^{\mathrm{ab}}$ & $39.63^{\mathrm{ab}}$ & $16.12^{\mathrm{ab}}$ & $324.60^{\mathrm{ab}}$ & $22.17^{\mathrm{ab}}$ & $14.79^{\mathrm{b}}$ & $1.61^{\mathrm{b}}$ & $6.43^{\mathrm{a}}$ \\
\hline $\begin{array}{c}\text { CV }(\%) \\
\text { Mean }\end{array}$ & 3.72 & 3.98 & 10.74 & 14.29 & 21.21 & 14.56 & 5.60 & 1.41 \\
\hline
\end{tabular}

Means followed by the same letter in the column do not differ according to Tukey's test at 5\% probability.

In general, the treatment with the $30 \%$ leaching fraction showed the best results. Figure 1 shows the results of the regressions regarding the application of the different leaching fractions and the different evaluated parameters. The results demonstrate the effectiveness of the use of a leaching fraction in the control of substrate salinity and that excessive leaching can be harmful, most likely by washing the necessary nutrients off the plant [15].

Ferreira et al. (2019) [7] studied five varieties of strawberries with respect to salinity, including the San Andreas, and found that different levels of salinity influenced the production of this variety. The use of irrigation water with $1.5 \mathrm{dS} \mathrm{m}^{-1}$, equal to that used in the current study, promoted a considerable reduction in yield when compared to the use of a water with conductivity of $0.7 \mathrm{dS} \mathrm{m}{ }^{-1}$; however, the study of those authors was conducted in soil, where the response to irrigation water with different saline levels may be different from the response observed when strawberries are grown in substrate.

In the case of cultivation using a substrate and grown in open field, where no drained solution recirculation occurs, the use of a leaching fraction is justified to maintain the substrate salinity levels at a level acceptable for the crop. As expected, the use of the leaching fraction was beneficial until a certain point for most of the evaluated parameters, after which it was harmful, probably due to excess nutrient leaching.

Regarding the number of fruits per plant, this variable was not determined as a function of the treatments, which differs from Ferreira et al. (2019) [7], who obtained a marked decrease in the number of fruits per plant with increasing salinity for the San Andreas variety.

The treatment with leaching fraction equivalent to $30 \%$ surplus irrigation, which did not show the lowest EC in the drained solution, showed a higher mean fruit mass than the other treatments, reaching $17.1 \mathrm{~g}$ per fruit, a result higher than that found by Radin et al. (2011) [16], which was 12.7 g per fruit. 

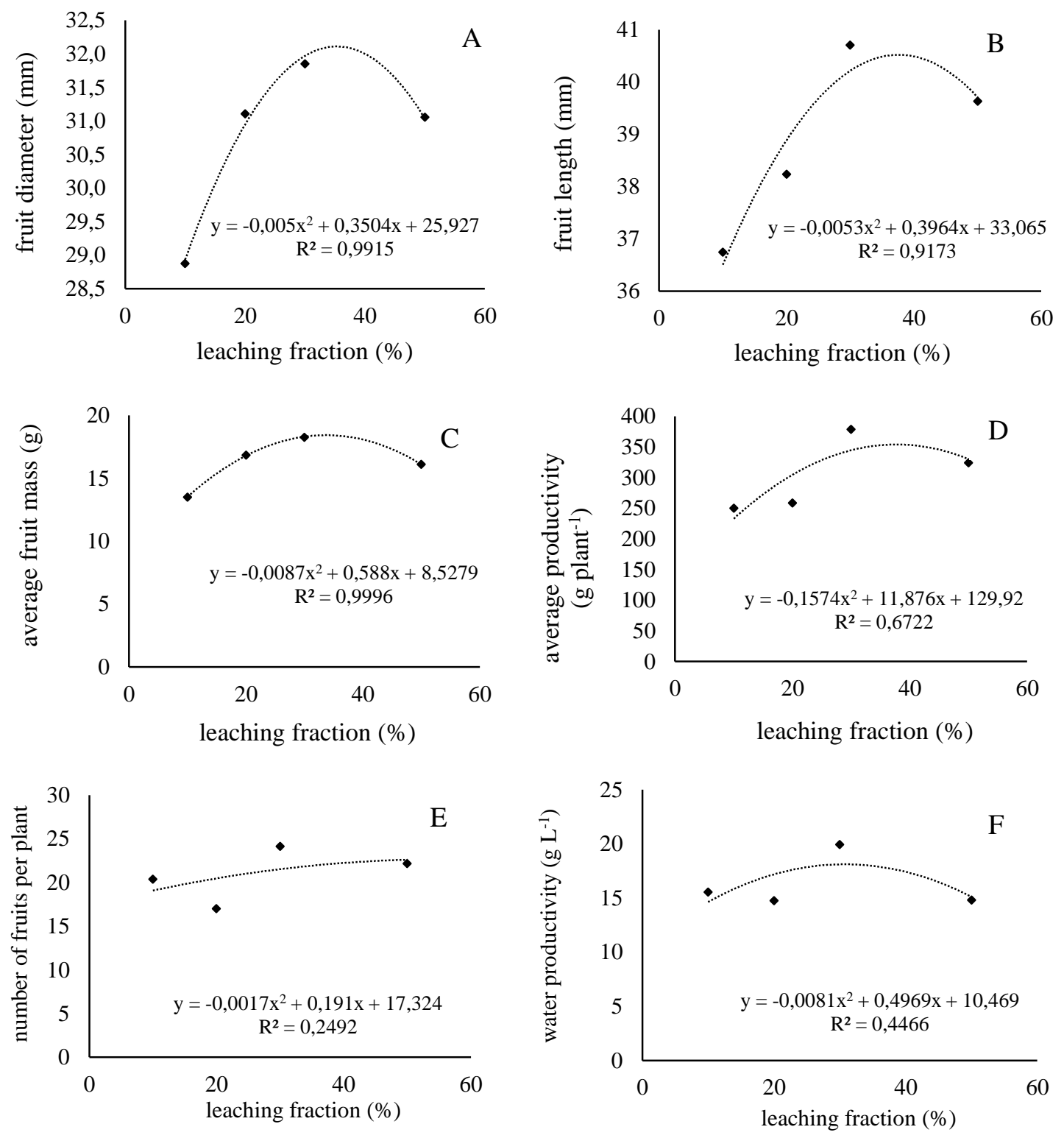

Figure 1. Correlation between leaching fraction and fruit diameter $(A)$, fruit length $(B)$, average fruit mass $(C)$, productivity $(D)$, number of fruits per plant $(E)$, and water productivity $(F)$ of strawberry.

The fruit yield was $378.9 \mathrm{~g} \mathrm{plant}^{-1}$ in the treatment that received $30 \%$ more water to promote leaching. This value is slightly below the mean value presented by Ferreira et al. (2019) [7], which was approximately $465 \mathrm{~g} \mathrm{plant}^{-1}$ for the San Andreas variety. Palencia et al. (2016) [3], when evaluating the effect of different substrates in three strawberry varieties (Camarosa, Candonga, and Festival), found even higher values, approximately $911 \mathrm{~g}$ plant ${ }^{-1}$, but that experiment lasted for a much longer period than the experiment in the current study; in addition, the evaluated varieties are different. That same author emphasizes the difference that can be found between varieties and even between the substrates used in production. The mean commercial yield of the three varieties (Earlibrite, Florida Festival, and Camino Real) reported by Antunes et al. (2016) [2] were $515 \mathrm{~g}^{\text {plant }}{ }^{-1}$, which was slightly higher than the values found in the present study.

The electrical conductivity (EC) and the $\mathrm{pH}$ varied with the leaching fraction applied in each treatment. With respect to electrical conductivity, the application of $50 \%$ LF was very efficient in its reduction. The $\mathrm{pH}$ in turn showed the highest values in the treatment that received the largest leaching fraction. According to Giménez et al. (2008) [5], variations occur due to the dynamics of water and nutrient absorption. The leaching fraction recommended by Gonçalves et al. (2016) [17] for drainage to occur, thereby removing the salts near the roots, is $30 \%$, a value close to the value found for the best results of the evaluated parameters, even though this leaching fraction was not the one with the lowest electrical conductivity of the drained solution. 
The electrical conductivity of the drained solution of the different treatments followed a quadratic polynomial trend (Figure 2). With the increase in the leaching fraction, as expected, a reduction occurred in the EC. The highest production (378.9 $\left.\mathrm{g} \mathrm{plant}^{-1}\right)$ was obtained with an EC of $1.93 \mathrm{dS} \mathrm{m}^{-1}$, which is lower than that obtained by Portela et al. (2012) [18], which was $608.2 \mathrm{~g}$ plant ${ }^{-1}$ in an EC of $1.2 \mathrm{dS} \mathrm{m}^{-1}$, but this author had a 201 days cultivation cycle, and all fruits produced (commercial or noncommercial) were considered.

The $\mathrm{pH}$ of the drained solution also followed a quadratic polynomial trend (Figure 2) but with a considerable increase as the leaching fraction increased. This behavior demonstrates that excess leaching may be removing a very large amount of salts, including nutrients that are no longer available to plants.

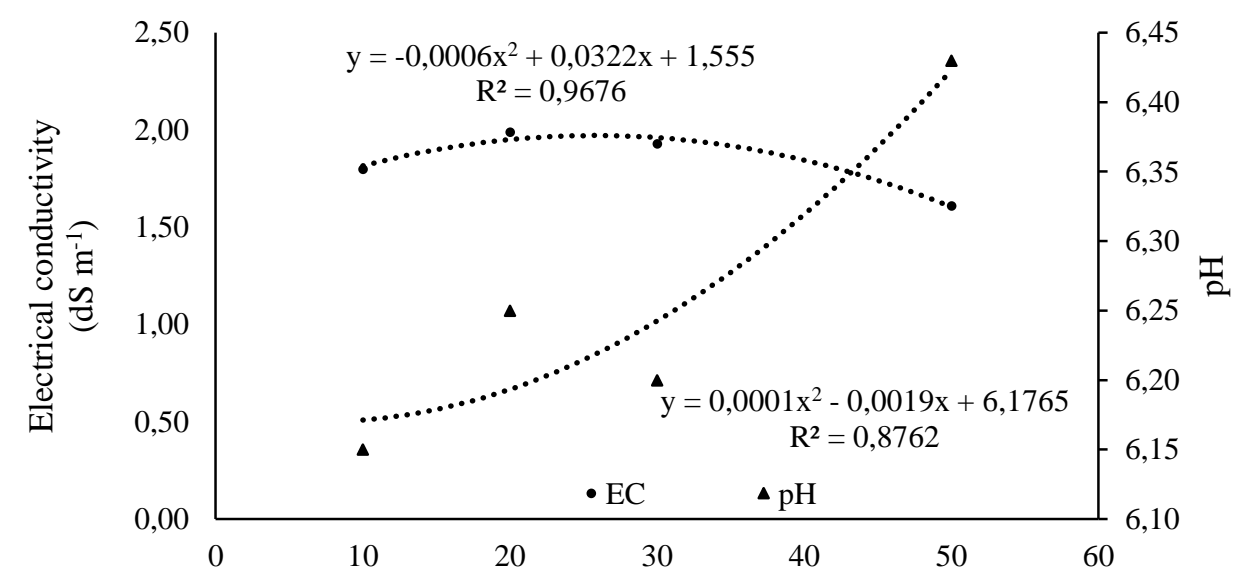

Figure 2. Electrical conductivity and $\mathrm{pH}$ of the drained solution as a function of the applied leaching fraction.

The water productivity between the different treatments showed a significant difference, and the treatment that received $30 \%$ excess water to promote leaching showed the best result. The water productivity value for the treatment with a leaching fraction of $30 \%$ was $19.92 \mathrm{~g}$ of fruit for each liter of solution consumed, which was $32 \%$ higher than the average for the other treatments. The values found were higher than those reported by Miranda et al. (2014) [19] for a system using gullies and no bags, which were 12.1 and $8.9 \mathrm{~g}$ of fruit, respectively.

The result is quite interesting because, even with the use of a leaching fraction of $30 \%$, the increase in productivity caused by this practice made the system more efficient with respect to water use when compared to the use of a leaching fraction of only 10 or $20 \%$.

\section{CONCLUSIONS}

The use of leaching fractions proved to be efficient for the control of salt levels in semihydroponic strawberry cultivation system, and a 30\% leaching fraction showed the best results.

Most of the evaluated characteristics showed a behavior in which the increase in the leaching fraction had a positive effect up to a value of approximately $30 \%$, but the effect was negative when the leaching fraction reached 50\% excess solution applied, probably due to excessive nutrient leaching.

In terms of water productivity, the application of $30 \%$ more nutrient solution to promote leaching was compensated by the increase in productivity, which made this the most efficient treatment, even though extra resources were used.

\section{ACKNOWLEDGMENTS}

This work was supported by the National Council for Scientific and Technological Development (CNPq). 


\section{REFERENCES}

1. Tazzo IF, Fagherazzi AF, Lerin S, et al. Exigência térmica de duas seleções e quatro cultivares de morangueiro cultivado no planalto catarinense. Rev Bras Frutic 2015; 37: 550-558. doi 10.1590/01002945-097/14.

2. Antunes LEC, Júnior CR, Schwengber JE. Morangueiro. Brasília, DF. Embrapa Clima Temperado, 589 p. 2016.

3. Palencia P, Giné Bordonaba J, Martínez F, et al. Investigating the effect of different soilless substrates on strawberry productivity and fruit composition. Sci Hortic (Amsterdam) 2016; 203: 12-19. doi 10.1016/j.scienta.2016.03.005.

4. Gonçalves MA, Vignolo GK, Antunes LEC, et al. Produção de Morango Fora do Solo. Pelotas, RS, 2019. Embrapa Clima Temperado, 32 p.

5. Giménez G, Andriolo J, Godoi R. Strawberry soilless cultivation. Cienc Rural 2008; 38: 273-279. doi $10.1590 /$ S0103-84782008000100048.

6. Karlidag H, Yildirim E, Turan M. Salicylic acid ameliorates the adverse effect of salt stress on strawberry. Sci Agric 2009; 66: 180-187. doi 10.1590/S0103-90162009000200006.

7. Ferreira JFS, Liu X, Suarez DL. Fruit yield and survival of five commercial strawberry cultivars under field cultivation and salinity stress. Sci Hortic (Amsterdam) 2019; 243: 401-410. doi 10.1016/j.scienta.2018.07.016.

8. Grieve CM, Grattan SR, Maas E V. Chapter 13 Plant Salt Tolerance. Agric Salin Assess Manag (2nd Ed 2012; 405-459.

9. Allen RG, Pereira LS, Raes D, et al. Crop Evapotranspiration (guidelines for computing crop water requirements). Food and Agriculture Organization of the United Nations. Epub ahead of print 1998. DOI: 10.1016/j.eja.2010.12.001.

10. van Halsema GE, Vincent L. Efficiency and productivity terms for water management: A matter of contextual relativism versus general absolutism. Agric Water Manag 2012; doi 10.1016/j.agwat.2011.05.016.

11. Alvares CA, Stape JL, Sentelhas PC, et al. Köppen's climate classification map for Brazil. Meteorol Zeitschrift 2013; 22: 711-728. doi 10.1127/0941-2948/2013/0507.

12. Furlani PR, Fernandes-Junior F. Cultivo hidropônico de morango em ambiente protegido. In: Resumos do II Simpósio Nacional do Morango e do I Encontro de Pequenas Frutas e Frutas Nativas do, p. 102/115.

13. Bortolozzo AR, Sanhueza RMV, Melo GWB de, et al. Produção de morangos no sistema semihidropônico, 2007. Embrapa Uva e Vinho, 24 p.

14. Calvete EO, Nienow AA, Wesp C de L, et al. Produção hidropônica de morangueiro em sistema de colunas verticais, sob cultivo protegido. Rev Bras Frutic 2007; 29: 524-529. doi 10.1590/s010029452007000300022.

15. Sousa VE., Marouelli WA, Coelho EF., et al. Irrigação e fertirrigaçao em fruteiras e hortaliças. Embrapa Informação Tecnológica, 2011. 769 p.

16. Radin B, Lisboa BB, Witter S, et al. Desempenho de quatro cultivares de morangueiro em duas regiões ecoclimáticas do Rio Grande do Sul. Hortic Bras 2011; 29: 287-291. doi 10.1590/S010205362011000300005 .

17. Francisco JP, Folegatti MV, Silva LBD, et al. Variations in the chemical composition of the solution extracted from a Latosol under fertigation with vinasse. Rev Ciência Agronomica 2016; 47: 229-239. doi 10.5935/1806-6690.20160027.

18. Portela P. I, Marins Nogueira Peil R, Rodrigues S, et al. Concentração de nutrientes da solução nutritiva: crescimento e produtividade de morangueiro em sistema hidropônico NFT. Hortic Bras; 30, 2019.

19. Miranda FR, Silva VB, Santos FSR, et al. Produtividade e Eficiência de Utilização da Água do Morangueiro em Cultivo Hidropônico Fechado Utilizando Substrato de Fibra de Coco. In: Anais do II Inovagri International Meeting - 2014. Fortaleza, Ceará, Brasil: INOVAGRI/INCT-EI/INCTSal, pp. 1181-1186. doi 10.12702/ii.inovagri.2014-a158 